\title{
Financial Management as an Important Competitiveness Factor in SMEs Hotel Businesses in the State of Yucatan
}

\author{
Antonio Emmanuel Pérez Brito*, Martha Isabel Bojórquez Zapata \\ Facultad de Contaduria y Administracion.Universidad Autonoma de Yucatan.
}

*Corresponding Author: Antonio Emmanuel Pérez Brito, Facultad de Contaduria y

Administracion.Universidad Autonoma de Yucatan.

\begin{abstract}
Small and medium hotel enterprises in Yucatan state represent an important sector for the economic development of the state, however inadequate financial management leads to reduced profits and a short life expectancy. The objective of this study is to identify that a good financial management is a factor that greatly increases the competitiveness of organizations. For this work a bibliographical review of relevant articles from a range of authors was conducted.
\end{abstract}

Keywords: Small and medium hotel enterprises, financial management, competitiveness, Yucatan.

\section{INTRODUCTION}

Small and Medium Enterprises (SMEs) contribute greatly to the sustainability and competitiveness of global, national and local economies- indeed- they are the economic driver of most countries around the world. When pathways to competitiveness are not identified, closure will surely follow, which in turn gives rise to increased unemployment and gradually diminishing standards of living in the country as a whole. In Mexico SMEs account for most of the business sector and they face problems relating to survival and competitiveness (Bojórquez, Pérez and Basulto, 2015).

According to Macías (2003), not only are SMEs inescapable, they are also clearly indispensable as the principal creator of jobs and the primary generator of revenue in populations and among regions. They are key to the existence of big business and they play vital roles in social cohesion and economic mobility. For Bojórquez, Pérez and Basulto (2015) financial management is an important factor in competitiveness because the extent to which a company's leadership is able to think strategically about the management of sources of financing, sales growth, and profitability, and consider risks - defines how likely they are to enjoy long-term survival regardless of the area or market structure in which they operate.

One of the fundamental components of any system of business management is finance function, which is responsible for obtaining and allocating the necessary resources for the development of short and long-term business operations. The presence of this component, alongside the other business functions, is a desirable characteristic in any organization. In the case of SMEs, improved performance can be achieved through better use and coordination of finance management tools (Burk and Lehman, 2004), translating to superior results in terms of investment and access to sources of financing.

For conceptual and operational purposes, financial management is defined as a business process that stems from the formulation of an organizational strategy and encompasses the setting of goals, the selection of strategies and policies and the actioning and application of control mechanisms relating to financing and investment decisions that consider long and short term implications (Brealey and Myers, 2005; Suárez, 2003). Good financial management assumes an understanding of variables like financing, debt, profitability, growth, use of accounting and financial information and management control systems (MCSs). (Castán, 2005).

The objective of this study is to identify that a good financial management is a factor that greatly increases the competitiveness of organizations. 


\section{LITERATURE REVIEW}

\subsection{Hotel Sector}

SMEs within the hotel sector are key to tourism as a whole; this category of organizations creates jobs, generates direct investment and dynamism in the real estate sector and incentivizes other touristic activities thus impacting on the society and economy of the surrounding area (Gallardo and Avilés, 2015).

Mexico's Official Journal of the Federation (DOF) describes companies that operate in the hotel sector and Providers of Touristic and Hospitality Services and defines them as follows:

"Those that supply the infrastructure and means to offer services of lodging to tourists as well as those that supply catering and complementary services demanded by tourists, principally those located near airport terminals, bus terminals, train stations, museums, archaeological sites, Integrally Planned Centers (CIPs), beaches, sea ports, city centers, other touristic routes, circuits and destinations and any other space with touristic elements" (DOF, 2016, p.2/19).

The provision of touristic accommodation services happens in a variety of areas and with different amenities and specific services depending on the type of tourist at which the service is being aimed. As such, it has been recognized that hotel businesses, due to their diversity, have different strengths and can be classified into 16 types according to the Tourism Secretariat, the CONACYT (National Council of Science and Technology) and the Centre for Superior Studies in Tourism (2016):

1. Boutique

2. Luxury

3. Bed \& Breakfast

4. Events and Conventions

5. Roadside

6. Beach/Vacation

7. City Centre

8. Nature Reserve

9. City

10. Complete Services

11. Business

12. Limited Services

13. Express

14. Select Services

In turn, the quality of service is evaluated via the System of Hotel Classification, defined as follows:

A methodological tool based on a mechanism of self-evaluation regulated by the Tourism Secretariat, which allows accommodation establishments to better understand the status of their facilities and services offered and to be able to identify areas of opportunity, all rated through a star system. (DOF, 2016, p.1/19).

The same author makes clear that each variable adds value to the total rating which is symbolized using a star system, in total there are five categories to which are assigned a maximum of five stars, this being the best possible rating.

Comparability between types of accommodation remains a significant challenge in the sense that a tourist who hires a service in one context, will expect the same quality in other contexts (World Tourism Organization, 2015).

\subsection{Indicators for Hotel Management}

In terms of the management control of organizations, financial and non-financial indicators are used as tools to monitor and give continuity to a company's plans. Hotel businesses are no exception, as 
these indicators provide information that aid the decision-making of a variety of key divisionsin companies that operate within this sector (Ferrer y Gamboa. 2004).

Rivera (2014, p. 46) states:

The indicators of hotel management are a measure of different variables associated with an organization's objectives, expressed in terms of a quantitative base that defines the achievement and reach of the expected results. The value of the indicators is directly dependent on the accuracy of the measuring and is formulated by comparing results with expected results or indeed historical results, either way, these comparisons are an important starting point on the road towards the achievement of objectives.

Martorell (2014) states that the operability of a hotel business can be divided into two fundamental areas, to which indicators are applied:

- Operative divisions are those that offer services directly to the guest, these divisions generate both profits and costs. Within this category we find divisions like room management, restaurants, laundry, communications etc

- Functional divisions are considered cost centers (they do not generate profit) and they cannot be directly associated with services aimed at hotel guests. Within this category we find for example; administration, marketing, maintenance etc.

Moreno and Martín (2002) state that the Uniform System of Accounts for the Lodging Industry (USALI) supplies a series of variables and indicators that provide information for the management of hotel businesses, focussing particularly on information relevant to the hotel rooms themselves as they have a bearing on other types of consumption within the hotel. The most significant indicators referred to in USALI are classified into four variables:

1. Basic indicators:

- Number of hotel rooms

- Days the establishment is open

- Total staff numbers

- Number of guests per occupied room

- Average stay per guest

2. Expenditure and Revenue Indicators

- Percentage of profit of the rooms division over total income

- Percentage of rooms division staff expenses over total income

- Percentage of room revenue over total revenue

3. Average rate indicators:

- Average Room Rate or ARR.

- Average Bed Rate or ABR.

- Revenue Per Available Room or REVPAR.

It is important to mention that the concept of average rates is relative to the concept of occupancy, this second variable being largely insignificant unless analysed in relation to pricing.

4. Productivity Indicators

- Number of employees per available room.

- Number of employees per unoccupied room

- Number of employees per stay

Ferrer and Gamboa (2004) show that the results obtained by the rooms and food / beverages divisions - being profit centers - depend on the work done by departments like marketing, sales, maintenance, security, human resources and financial management. 
Gallego (1987) cited by Ferrer (2004) proposes a series of indicators - perhaps better described as efficiency measures - which focus directlyon evaluating the performance of divisions such as rooms and drinks/beverages, while looking indirectly at divisions like maintenance and personnel. The indicators proposed by the author are grouped into twelve categories:

1. Room occupancy

2. Diet

3. Customer Groups

4. Source of Occupancy

5. Nationality

6. Restaurant

7. Sports Facilities

8. Staff

9. Revenue

10. Expenses

11. Costs

12. Other economic data

For his part Martorell (2014) groups hotel indicators into two types:

- Economic Indicators focus on how the hotel generates results (profits or losses) and how to improve them

- Financial Indicators focus on the financial structure of the company in terms of financing and capacity to repay said financing

Rivera (2014) classifies indicators for financial analysis of organizations into two types:

- Operative Indicators measure the operational performance of hotel businesses through revenue generation, average rates, RevPAR, average check, $\%$ of departmental profit, \% of indirect expenses over total revenue, cost analysis and profit margins

- Financial Indicators measure the capacity to generate profit and cash flow, both necessary to meet financial commitments such as:

- Interest coverage

- Capital and interest coverage

- Working capital

- Quick ratio

- Accounts receivable turnover

- Days sales outstanding

Likewise, Rivera (2014) mentions the existence of a set of financial indicators, namely:

- Financial contribution

- Cash generated from operations

- Marginal profit

- Return on assets

- Productivity of net operating working capital

- Contribution index 
Tsai, Hsu, Chen, Lin and Chen (2009), quoted by Millan-García and Gómez-Díaz (2018), show that hotel business management results are expressed in terms of market share and price, which are then compared with those of the competition. As such, in the hotel industry various measurements are used to gauge results, such as occupancy rate (GOT), RevPAR (which includes GOT data) and Total Revenue Per Avaliable Room (TRevPAR), among others (Millán-García and Gómez-Díaz, 2018).

The abovementioned indicators are described below, in accordance with definitions in Millán-García and Gómez-Díaz, (2018):

- The GOT indicator in hospitality describes capacity to manage profitability and is calculated by subtracting the direct costs and both direct and indirect expenses from revenue. Regarding this indicator Rivera (2014) states the importance of considering the vocation of the hotel as well as its category and location to determine the margins of profitability and gauge the financial performance of the business. As an example, it is stated that a city hotel does not generate margins of profitability comparable to those generated when operating a hacienda style hotel.

- The occupancy rate is an indicator that relates the total available rooms available to rent in a day (or for a given timeframe) with the rooms that are in fact rented.

- RevPAR, also highlighted by Martin (2002), is used as an indicator of financial performance, in that it shows the average rate of those rooms that have been rented during the given timeframe. This index is useful in the hotel sector as it shows the elasticity of the rates that are charged, above all in those organizations that offer a variety room types with differing tariffs.

Table 1 (below) shows indicators for management control of hotel businesses as suggested by several authors:

Table1. Financial Indicators for Hotel Businesses

\begin{tabular}{|c|c|}
\hline Author & \\
\hline $\begin{array}{l}\text { Engstrom, Westnes and Westnes } \\
(2003)\end{array}$ & $\begin{array}{l}\text { GOP; RevPAR; Porcentaje de ocupación; Beneficios por hospedaje; } \\
\text { Beneficios por A y B; Costos de Personal }\end{array}$ \\
\hline Ferrer and Gamboa (2004) & $\begin{array}{l}\text { Ocupación habitaciones; Tarifa promedio; Densidad por segmento de } \\
\text { mercado; Productividad del mercadeo alojamiento; Plazo de cobro a } \\
\text { clientes; Plazo de pago proveedores; Marge Neto; Rotación del activo } \\
\text { operativo; }\end{array}$ \\
\hline $\begin{array}{l}\text { Campos-Soria, González and } \\
\text { Ropero, (2005) }\end{array}$ & $\begin{array}{l}\text { medio; Porcentaje de ocupación; Promedio de costos directos; } \\
\text { de Costos indirectos; Rentabilidad por habitación }\end{array}$ \\
\hline $\begin{array}{l}\text { Kim, Kim, Park, Lee and Jee } \\
\text { (2012) }\end{array}$ & $\begin{array}{l}\text { evPAR; Razón de incremento de ventas; Razón de incremento de } \\
\text { s }\end{array}$ \\
\hline Rivera (2014) & $\begin{array}{l}\text { Porcentaje ocupación hotel; Tarifa promedio; RevPAR; Cheque } \\
\text { Promedio; Cobertura de intereses; Cobertura de capital e intereses; capital } \\
\text { de trabajo; prueba de ácido }\end{array}$ \\
\hline $\begin{array}{l}\text { Bontis, Janosevic } \\
\text { Dzenopoljak (2015) }\end{array}$ & $\begin{array}{l}\text { Ganancia operativa; ROE (calculado a partir de la razón entre el beneficio } \\
\text { neto y el valor contable); ROA; Productividad y Productividad por } \\
\text { empleados }\end{array}$ \\
\hline $\begin{array}{l}\text { Aznar, Bagur and Rocafort } \\
(2016)\end{array}$ & Variación de importes netos, variación de empleo, cuota de mercado \\
\hline $\begin{array}{l}\text { Millan-García and Gómez-Díaz } \\
\text { (2018) }\end{array}$ & $\begin{array}{l}\text { Ganancia operativa bruta (GOT); Porcentaje de ocupación; RevPAR; } \\
\text { Tarifa Promedio; TrevPAR; Cuota de Mercado }\end{array}$ \\
\hline Ferná & $\begin{array}{l}\text { arifa diaria promedio (ADR); Ingresos por habitación disponible } \\
\text { RevPAR); RevPAR mínimo para obtener beneficios; Duración media de } \\
\text { stancia; Ganancia operativa bruta por habitación disponible (GOPPAR) }\end{array}$ \\
\hline
\end{tabular}

Source: authors' own

Using an indicator to measure the performance management of a business naturally means also applying a methodology for the implementation of indicators. Rivera (2914, p. 50) suggests the following steps for this implementation.

1. Define what is to be measured and the number of indicators to be used, grouping them as follows: Financial, Client, Partners, Processes. Establish for each one a strategic goal.

2. Consider no more than five goals for each indicator. 
3. Identify the measuring method and expected results.

4. Establish the indicators to measure the objectives firstly of the organization and then of the main executives in each management area.

5. Measure results monthly, bi-monthly or tri-monthly.

6. Based on results, take necessary decisions and/or actions.

7. Designate a key executive to oversee the measuring and presentation of results.

\subsection{Financial Management and Competitiveness}

Ibarra, Gonzalez and Demunier (2017) mention that with regard to competitiveness- both on a microeconomy and business level- eight dimensions can be distinguished, of which one is finance and accounting where analysis focusses on whether the business has defined profit margins, financial administration and planning, cost structures, fiscal strategy, tax payments etc. Additionally, the success of failure of businesses is to a great extent related to financing and investment strategy (Saavedra and Tapia, 2011).

Moreover, business competitiveness studies have led to the conclusion that among the small businesses of Estado de Mexico, Hidalgo, Puebla and Sonora; the areas facing the greatest challenges were administrative planning, human resources and information technology, with the financial area receiving the best score (Red PYMES-Cumex, 2010). Similarly, Rosto (2010) mentions that in relation to business competitiveness in Mexico, it is the financial sphere that has the greatest relevance, and without strategic market planning and the adoption of a clear administrative model by owners and managers, strong competitiveness will be impeded. According to Molina, Armenteros, Medina, Barquero and Espinoza (2011)

Gitman, as quoted by Pérez, Bojórquez, Nuño and Santillana (2015), states that financial resources serve to maintain the solvency of a business through the supply of the cashflow necessary to satisfy commitments and acquire the current assets required for the company to meet its objectives and improve competitiveness. In order to have financial resources available it is necessary to mediate between profit and financing. For David (2003, p. 281-287), the use of financial data is essential to the implementation and development of strategies within the company and financial institutions are prepared to lend money to those projects that are profitable and that can guarantee repayment, for this he establishes the following steps for demonstrating viability:

Determine the amount of capital that is needed

1) Prepare pro forma financial statements

2) Prepare financial budgets

3) Calculate the value of the business

In 1990, Birley and Westhead, quoted by Perez et al. (2015), stated that the maintenance of good financial standards through correct financial management is one of the main and most necessary factors requirements for achieving competitive success.

Through studies on competitive strategies, Karplan and Norton (2004), quoted by Román, Arbeláez and Patiño (2012), were able to summarize four dimensions of comprehensive management to lead the company along a desirable probable future path (competitiveness) and thus survival or durability. One such dimension is financial, specifically an increase in revenue and a reduction of costs leading to greater profits. Likewise the authors mention the "Acropolis of competitiveness" which has at its base the management of human talent and processes respectively, and has at its summit commercial results among which Economic Value Added (EVA), cost-effectiveness, growth, profitability, sales and customer satisfaction are paramount. Companies have many goals but for Sallenave (1994, p. 86101), these can be reduced to three: cost-effectiveness, growth and survival. The same author states that there are four fundamental notions related to cost-effectiveness:

Return on Sales (ROS), is calculated by dividing the operating profit by the net sales for the period.

Return on Assets (ROA), is calculated by dividing net income by average total assets

The objective is to increase profits and reduce total capital without causing costs to rise. 
Return on Equity (ROE), determines the profitability of capital or assets and is a ratio of net income to shareholder equity.

\section{Project Profitability}

In order to avoid stasis, it is essential to find dynamic future performance indices like net present value (NPV), which is defined as the sum of current and future cash flow adjusted in line with capital costs. A competitive strategy in the finance department involves the establishment of a "functional strategy" to attempt to resolve uncertainty about how to use resources and organize capacity within the division. The aim is to maximize the productivity of the resources administered by the department (thus contributing to the building of competitive advantage and consequently to the competitiveness levels of the company as a whole).

In this sense, the competitiveness strategy of a company should serve as a guide to capital structure and asset investment. Those companies that apply management strategy concepts are more profitable and more successful than those that don't; they both register more sales and reach greater levels of productivity and competitiveness.

According to Bravo, (2010); David, (2003) cited by Pérez et al. (2015); given that the finance department administers company money, if the strategic lines to improve competitiveness require the acquisition of assets like machinery or human resources, it is this department that must come up with sustainable strategies to put them into practice or indeed warn againstunrealistic objectives proposed by other functional business areas if such warnings were deemed necessary.

According to Magretta (2012), for Porter the only financial measure that represents the multidimensional nature of competitiveness is Return of Invested Capital (ROIC), which is calculated by dividing net revenue minus dividends between by total capital.

For Burk and Lehnman (2004), good financial management of SMEs becomes a key area of interest for the business itself, given that it is a necessary condition for them to survive and mature within their business ecosystem. A primary concern is the efficient capture of resources to facilitate the necessary long- and short-term investments. Long-term financial management therefore concerns itself with future planning for the business in search of adequate fixed investment in which underuse may be avoided, as well as controlling the profitability created by these investments and attempting to optimize them. Additionally, it will analyse the capacity for the company to take on debt.

On the other hand, short-term financial management focusses on the challenges of financing current assets. Put another way, it ensures the availability of funds to meet the needs of short-term investments (stocks, defaulting customers, treasury) with the aim of avoiding any stoppages in the operating cycle, as any lag between collection and payment could give rise to negative cash flow; hence the need to have fallback resources in the treasury fund.

For Tarragó (1989), one purpose of financial management is to maintain an optimum level of debt for the company. With this index it is possible to evaluate the future debt capacity of the business. While at the same time showing the proportion of assets that belong to lenders. This index can suggest whether the company is operating with high or low risk levels, as greater debt implies greater risk.

Growth is difficult for any mature business, whether family-run or not, because markets evolve, competition intensifies and technology changes. The business life cycle identified by Schumpter (1990) is the natural order for all companies, and it again shows the importance of good financial management.

For Machado (1999), a key aspect of good financial management is accounting and financial data, which is the basis for the Government's fiscal calculations, the gathering of statistics, sectorial analysis in terms of growth and development and of course public trust through administrative transparency and integrity.

\section{CONCLuSion}

Financial management is the hugely important process for businesses, it is after all part of the handbook for the correct use of financial resources. Such management in small and medium enterprises can be hugely beneficial to small-scale entrepreneurs. Good financial management helps to 
increase the capacity of a business to survive when operating conditions are unfavourable or uncertain. The effective use of financial data can aid the small-scale entrepreneur greatly in managing the financial future of the enterprise. Through the modelling of various scenarios, a series of combinations of decisions can be considered, helping to anticipate problems that may arise downstream.

The relatively few studies conducted around this topic in Mexico show that a large proportion of businesses plan in the short term through income and expenditure budgets, while longer term financial plans may only be used by approximately half of businesses on average. This puts SMEs in the vulnerable position of not having in their toolkits the necessary strategies to confront environmental changes. SMEs are at risk of suffering unexpected financial imbalances - often in the form of insolvency or lack of liquidity - as a result of ineffective financial policies or as a result of the owner/manager not knowing enough about the administration, planning and adequate management of resources.

\section{REFERENCES}

[1] Aznar, J., Bagur, L., Rocafort A. (2016). Impacto de la calidad del servicio en la competitividad y rentabilidad: El sector hotelero en la costa catalana. Intangible Capital, 12(1), 147-166.

[2] Bojórquez, M., Pérez, A., y Basulto, J. (2015). La gestión financiera, un factor para elevar la competitividad en las pymes de la industria del vestido en Yucatán.México: UADY.

[3] Bontis, N., Janosevic, S.y Dzenopoljac, V. (2015). Intellectual capital in Serbia's hotel industry. International Journal of Contemporary Hospitality Management, 27(6) 1365-1384.

[4] Brealey, R. y Myers, S. (2005). Principios de Finanzas Corporativas. México: McGraw-Hill.

[5] Burk, J. y Lehnman, R. (2004). Financing Your Small Business. Estados Unidos: Sphinx Publishing.

[6] Campos-Soria, J., González, L., Ropero, M. (2005). Service quality and competitiveness in the hospitality sector. Tourism Economics, 11 (1), 85-102.

[7] Castán, J. (2005). Fundamentos y aplicaciones de la gestión financiera de la empresa. México: Editorial Pirámide.

[8] David, F. (2003). Conceptos de Administración Estratégica. México: Pearson Editores.

[9] Diario Oficial de la Federación (2016). Acuerdo por el que se emiten los Lineamientos del Sistema de Clasificación Hotelera. Recuperado en: https://www.gob.mx/cms/uploads/attachment/file/135623/LINEA MIENTOS-SCH-_DOF. pdf

[10] Engstrom, T., Westnes, P., Westnes, S. (2003). Evaluating intellectual capital in the hotel industry. Journal of Intellectual Capital, 4 (3), 287-303.

[11] Fernández, E. (2019) Principales métricas y KPIs para el sector hotelero. Recuperado de: https://artyco .com/principales-metricas-y-kpis-para-el-sector-hotelero/

[12] Ferrer, M. (2004). Control de gestión para procesos de apoyo hoteleros, en Revista Venezolana de Gerencia, 9 (27) 490-507

[13] Ferrer, M. y Gamboa, T. Indicadores para el Control de Gestión de Procesos Básicos en Hoteles, en Actualidad Contable Faces, 7 (8) 50-61

[14] Ibarra, M. González, L. y Demuner, M. (2017). Competitividad empresarial de las pequeñas y medianas empresas manufactureras de Baja California. Estudios Fronterizos. 35(18) 107-130.

[15] Gallardo, L y Avilés. E. (2015) Estructura de capital y riesgo financiero: evidencia empírica en PyMES hoteleras. Revista Global de Negocios 3 (4), 1-10

[16] Kim, T., Kim, W., Park, S., Lee, G., Jee, B. (2012). Intellectual capital and business performance: what structural relationships do they have in upper-upscale hotels? International Journal of Tourism Research, 14(4), 391-408.

[17] Machado, M. (1999). El complejo objeto de estudio de la Contabilidad: por la vía constructiva. Revista Contaduría. 36, 17-47.

[18] Macías, S. (2003). La importancia de las Pymes para el mercado mexicano. Recuperado de: http://compite. org.mx /otros/importanciapymes.pdf

[19] Magretta, J. (2012). Understanding Michael Porter. Estados Unidos: Harvard Business Review Press.

[20] Martorell, P. (2014) Algunos ratios hoteleros. Recuperado de: https://onlyhotels.wordpress.com/2014/12 /05/algunos-ratios-hoteleros/

[21] Millán-García, C. y Gómez-Díaz, M. (2018) Factores e indicadores de competitividad hotelera, en Compendium. 21 (40). Recuperado de: https://www.redalyc.org/jatsRepo/880/88055200021/html/index .html 
[22] Molina, V., Armenteros, M., Medina, M., Barquero, J. y Espinoza, J. (2011). Reflexión sobre la sobrevivencia de las pyme en el estado de Coahuila, México. Revista Internacional Administración \& Finanzas, 4(1), 47-66.

[23] Moreno, J. y Martín, R. (2002) La Información Contable para la gestión en la empresa hotelera: el Uniform System of Accounts for the Lodging Industry (USALI), en Cuadernos de Ciencias Económicas y Empresariales. 1 (43), 57-75. Recuperado de: https://idus.us.es/xmlui/handle/11441/85192

[24] Organización Mundial del Turismo (2001) Código ético mundial para el turismo. Recuperado en: http://www.ugto.mx/images/eventos/06-07-16/codigo-etico-mundial-turismo.pdf

[25] Pérez, A., Bojórquez, M., Nuño de la Parra, J. y Santillana, J. (2015). El Modelo Clúster y la Filosofía Lean en la ganadería Bovina de Yucatán. México. Editorial: Universidad Popular Autónoma de Puebla.

[26] Red PYMES-Cumex. (2010). Un estudio comparativo del perfil financiero y administrativo de las pequeñas empresas en México: entidades del Estado de México, Hidalgo, Puebla, Sonora y Tamaulipas. Resultados finales. Revista del Centro de Investigación, 9(33), 5-30

[27] Rivera, L. (2014).La Magia de las Finanzas en la Hotelería. México: CESSA

[28] Román, O., Arbeláez, G. y Patiño, C. (2012). Gerencia integral desde la perspectiva de un modelo de planeación estratégica. Gestión y Desarrollo, 9 (1), 51-78.

[29] Rosto, F. (2010). General diagnosis of Mexican SME's from the perspective of the marketing practices efficiency: The importance of strategic market planning as a source of competitive advantage creation.Ide@s CONCYTEG, 5(65), 1335-1363.

[30] Saavedra, M. y Tapia, B. (2011). Mejores prácticas y factores de competitividad en las micro, pequeñas y medianas empresas mexicanas. Economía, 36(32), 11-36.

[31] Sallenave, J. (1994). La gerencia integral. Colombia: Grupo Editorial Norma.

[32] Schumpeter, J. (1990). Essays on entrepreneurs, innovations, business cycles, and the evolution of capitalism. The Journal of Economic History, 50, 246-247.

[33] Secretaria de Turismo, Conacyt y Centro de Estudios Superiores en Turismo (2016). Sistema de Clasificación Hotelera Mexicano. Recuperado en: http://www.entornoturistico.com/wpcontent/uploads/2016/08/ClasificacionHotelera_FactorDelta_VersionCorta.pdf

[34] Suárez, A. (2003). Decisiones óptimas de inversión y financiación en la empresa. España: Ediciones Pirámide.

[35] Tarragó, F. (1989). Fundamentos de la economía de la empresa. España: Hispano Americana.

\section{AUTHORS' BIOGRAPHIES}

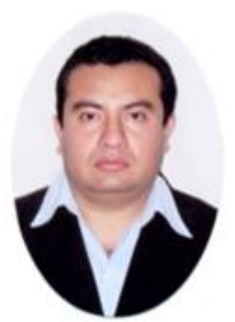

Antonio Emmanuel Perez Brito, Ph.D., from Universidad Popular Autonoma del Estado de Puebla (August 2014), is Professor of finance at the Facultad de Contaduria $y$ Administracion of the Universidad Autonoma de Yucatan (antonio.perez@correo.uady.mx). Current research interestsinclude competitiveness and financial management.

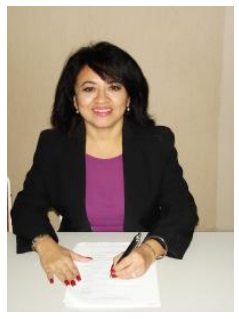

Martha Isabel Bojorquez Zapata, Ph.D., from Universidad del Sur (March 2013), is Professor of finance at the Facultad de Contaduria $y$ Administracion of the Universidad Autonoma de Yucatan (mbzapata@correo.uady.mx). Current research interestsinclude competitiveness and financial management.

Citation: Antonio Emmanuel Pérez Brito, Martha Isabel Bojórquez Zapata. "Financial Management as an Important Competitiveness Factor in SMEs Hotel Businesses in the State of Yucatan" International Journal of Managerial Studies and Research (IJMSR), vol 8, no. 8, 2020, pp. 20-28. doi: https://doi.org/10.20431/23490349.0808003.

Copyright: (C) 2020 Authors. This is an open-access article distributed under the terms of the Creative Commons Attribution License, which permits unrestricted use, distribution, and reproduction in any medium, provided the original author and source are credited. 